\title{
Late Miocene bovids from Şerefköy-2 (SW Turkey) and their position within the sub-Paratethyan biogeographic province
}

Dimitris S. Kostopoulos and Seval Karakütük

Acta Palaeontologica Polonica 60 (1), 2015: 49-66 doi: http://dx.doi.org/10.4202/app.2012.0129

We describe new fossil bovid craniodental remains from the Upper Miocene fossil site of Şerefköy-2, Yatağan Basin,

SW Turkey. The new material belongs to six species: Gazella cf. G. capricornis, Palaeoryx pallasi, Sporadotragus parvidens, Skoufotragus cf. Sk. schlosseri, Urmiatherium rugosifrons, and ?Sinotragus sp., which together indicate a latest middle-early Late Turolian (Late Miocene) age. Medium-to-large bovid taxa prevail over small ones, and protoryxoid bovids clearly dominate the assemblage. An analysis of the taxonomic structure, size and diet spectra of several Turolian bovid assemblages from Greece and Turkey reveals Şerefköy-2 to be a member of a mammalian palaeocommunity particular to southwestern Anatolia, which in turn forms part of the sub-Paratethyan biogeographic province.

Key words: Mammalia, Bovidae, Antilopinae, biogeography, Miocene, Turolian, Turkey, Anatolia.

Dimitris S. Kostopoulos [dkostop@geo.auth.gr], Aristotle University of Thessaloniki, School of Geology, 54124 Thessaloniki, Greece;

Seval Karakutuk [sevaloruc.ege.univ@ hotmail.com], Natural History Museum, Ege University, 35100 Izmir, Turkey.

This is an open-access article distributed under the terms of the Creative Commons Attribution License (for details please see creativecommons.org), which permits unrestricted use, distribution, and reproduction in any medium, provided the original author and source are credited. 
